\title{
New records of benthic marine macroalgae from the Caribbean coast of Costa Rica
}

\author{
Greivin Vega-Álvarez ${ }^{1,2}$, Juan Carlos Azofeifa-Solano ${ }^{2,4}$, Cindy Fernández-García ${ }^{1,2,3}$, \\ Rebeca Soto-Molinari ${ }^{1}$, Maricruz Rojas-Angulo ${ }^{1,2}$, Xaviera Amador-Fernández ${ }^{1}$ \\ \& Alejandra Vargas-Gamboa ${ }^{1}$ \\ 1. Escuela de Biología, Universidad de Costa Rica, 11501-2060 San José, Costa Rica; greivin.vegaalvarez@ucr.ac.cr; \\ rebe.sotomolinari@gmail.com; maricruz.rojas@ucr.ac.cr xavid2009@hotmail.com; ajvargamb@gmail.com \\ 2. Centro de Investigación en Ciencias del Mar y Limnología (CIMAR), Universidad de Costa Rica, 11501-2060 San \\ José, Costa Rica; cindy.fernandezgarcia@ucr.ac.cr; \\ 3. Herbario Dr. Luis A. Fournier Origgi, Universidad de Costa Rica, 11501-2060 San José, Costa Rica. \\ 4. Posgrado de Biología, Sistema de Estudios de Posgrado, Universidad de Costa Rica, 11501-2060 San José, Costa \\ Rica; juan.azofeifa@ucr.ac.cr
}

\section{Received 06-I-2017. C Corrected 29-I-2018. Accepted 08-II-2018.}

\begin{abstract}
Marine macroalgae are highly diverse and play an important role in marine ecosystems, influencing ecological processes. Recording the algae diversity with precise taxonomic identification is required to understand the marine ecosystems. The biodiversity of macroalgae along the southern Caribbean coast of Costa Rica has been studied by several authors, and the updated checklist includes 396 species of benthic marine algae reported for both Pacific and Caribbean coasts of Costa Rica, from which 287 are recorded from the Caribbean. Eighty percent of the total specimens from the Caribbean coast deposited in botanical collections in Costa Rica were collected at Cahuita National Park, an area where most of the studies have been carried out. This study reports on the addition of five new species and one genus of marine benthic macroalgae to the Caribbean Costa Rican flora, found at the poorly studied reefs of Playa Chiquita (Punta Cocles) and Punta Uva. Sampling was directed, searching for benthic macroalgae at Chiquita beach (SCUBA diving and snorkel) and Punta Uva (snorkel only), during October 2014. Specimens were deposited in the Dr. Luis A. Fournier Origgi Herbarium of the University of Costa Rica (USJ). Most of the new records were Chlorophyta, followed by Rhodophyta and Ochrophyta-Phaeophyceae. We recorded four new genera for the Caribbean coast of Costa Rica: Microdictyon Decaisne, 1841, Rhipidosiphon Montagne, 1842, Predaea G. De Toni, 1936, and Augophyllum S.-M. Lin, S. Fredericq \& M. H. Hommersand, 2003. In conclusion, is necessary to continue the detailed taxonomic works in the Caribbean coast, focusing on areas poorly studied, in order to improve our knowledge of the marine flora of Costa Rica. Rev. Biol. Trop. 66(Suppl. 1): S328-S339. Epub 2018 April 01.
\end{abstract}

Key words: Chlorophyta, collections, herbarium, marine biodiversity, Phaeophyceae, reef algae, Rhodophyta.

Marine macroalgae are a highly diverse group including different phyla and thousands of described species. These organisms play an important role in marine ecosystems as primary producers in littoral food webs and act as refuges for fish and invertebrates (Fletcher, 1987; Hay, 1981; Ruitton, Francour, \& Boudouresque, 2000). A better understanding of the identity and richness of macroalgae species is a first step for studying ecological processes, such as competition, nutrient flux, and biotic interactions. Recording the biodiversity with precise taxonomic identifications improve efforts to understand ecosystem functioning and the development of management tools (Bruno, Boyer, Duffy, Lee, \& Kertesz, 2005; Costello, Michener, Gahegan, Zhang, \& Bourne, 2013). 
The first records of marine macroalgae from the southern Caribbean coast of Costa Rica were made by Taylor (1933, 1942, 1960), Dawson (1962) and Wellington (1973, 1974). Later, Soto (1983), Soto \& Ballantine (1986), and Kemperman \& Stegenga (1986) provided the first comprehensive check lists of macroalgae. Then, Thomas \& Freshwater (2001) reviewed some species from the Order Gelidiales and reported on two new species. Fernández \& Alvarado (2004) later described the coral reef from Punta Cocles, including a list of the associated macroalgae. Then, Bernecker (2009) and Bernecker \& Wehrtmann (2009) published an updated list of the macroalgae from both the Caribbean and Pacific coasts of Costa Rica. There are 396 species of benthic marine algae reported for both Pacific and Caribbean coasts of Costa Rica (84 Chlorophyta or green algae, 51 Ochrophyta-Phaeophyceae or brown algae, 1 Xanthophyceae or yellow-green algae, and 260 Rhodophyta or red algae), from which 287 are recorded from the Caribbean coast (Bernecker, 2009). Fernández \& Alvarado (2004) found high coverage of macroalgae (up to $59 \%$ ) at Punta Cocles reef, being the brown algae the predominant group (Dictyota sp., Sargassum sp., Padina sp., and Dictyopteris delicatula J.V.Lamouroux).

Considering the records at the two main herbaria of Costa Rica -Dr. Luis A. Fournier Origgi Herbarium of the University of Costa Rica, and National Herbarium of Costa Ricathe Caribbean coast was relatively well sampled between 2000 and 2007, however there are no records for macroalgae collections from 2007 to 2014. Moreover, $80 \%$ of the total specimens from the Caribbean coast deposited in these two herbaria were collected in the Costa Rica's largest fringing reef at Cahuita National Park, where most prior studies have been carried out. However, other coral reef areas at the southern Caribbean, like Moín-Isla Uvita and Puerto Viejo-Punta Mona, have been far less studied. This study aims to report on the addition of six new marine benthic macroalgae records to the flora of Caribbean Costa Rica, found at the coral reefs from the Puerto ViejoPunta Mona area.

\section{MATERIALS AND METHODS}

Study site: Samples were collected at the coral reefs of Playa Chiquita $\left(9^{\circ} 38^{\prime} 43.29^{\prime \prime} \mathrm{N}\right.$; $\left.82^{\circ} 43^{\prime} 10.70^{\prime \prime} \mathrm{W}\right)$ and Punta Uva (9॰38'37.51" N; 82 41 '3.43" W), within the Puerto ViejoPunta Mona coral reef area in the southern Caribbean coast of Costa Rica (Fig. 1). Coastal environments from Cocles to Sixaola rivers are within the Gandoca-Manzanillo Wildlife Refuge (Refugio Nacional de Vida Silvestre Gandoca-Manzanillo) and therefore are protected areas (Fig. 1). Reefs at Punta Cocles have been relatively well studied (Cortés, Jiménez, Fonseca, \& Alvarado, 2010) with an average of 16 $\%$ and $59 \%$ live coral and macroalgae coverage, respectively. Additionally, 39 species of macroalgae were recorded during a 2002 survey (Fernández \& Alvarado, 2004). The reef at Playa Chiquita is a small and narrow fringing type reef with small buttresses (Cortés \& Jiménez, 2003). In Punta Uva the fringing reefs are located near the rocky points, while the patch reefs are found in lagoons and wave-protected areas (Cortés, 1992; Cortés et al., 2010).

Sample collection: Sampling was directed, searching for benthic macroalgae at Chiquita beach (SCUBA diving and snorkel) and Punta Uva (snorkel only), during October 2014. Seaweeds were stored in vials with $4 \%$ formalin, and transported to the laboratory of Phycology at Centro de Investigación en Ciencias del Mar y Limnología (CIMAR-UCR). Vouchers were deposited in the Dr. Luis A. Fournier Origgi Herbarium of the University of Costa Rica (USJ), San José, Costa Rica. Samples were collected under sampling permit (No. SINAC-SE-GCUS-PI-R-082-2015) provided by SINAC-MINAET.

Morphological identification: Algae were identified following original descriptions to corroborate identifications (Barton, 1891; Guiry \& Guiry, 2015; Kajimura, 1987; Lin, 


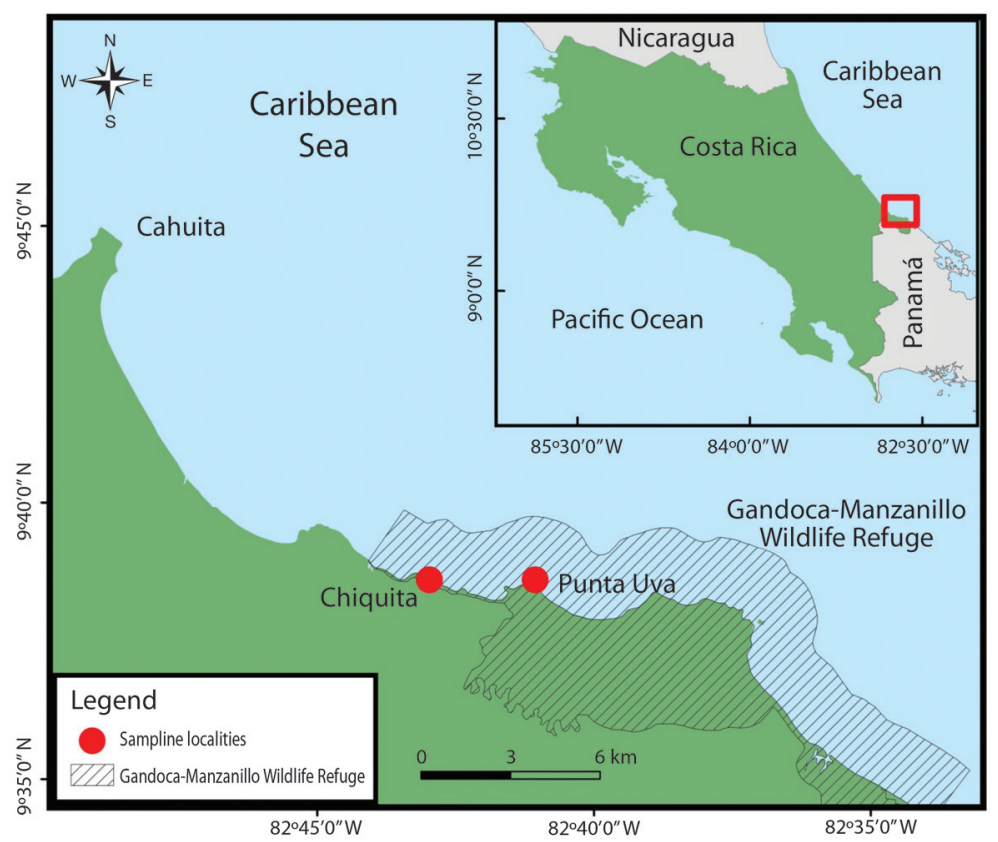

Fig. 1. Sampling localities of benthic marine macroalgae at Southern Caribbean coast of Costa Rica.

Fredericq, \& Hommersand, 2004; Littler \& Littler, 1992; Taylor, 1955). Photographs of the specimens were taken with a Canon PowerShot SX230 HS.

\section{RESULTS}

Based on morphological analysis, a total of five new macroalgae species and one new genus were recorded representing six families, five orders, and three classes; from Chlorophyta, Ochrophyta and Rhodophyta (Table 1). Here, we provide a brief description of the collected specimens, including USJ voucher number, habitat, distribution recorded in Costa Rica and some illustrative figures.

\section{Microdictyon curtissiae W. R. Taylor, 1955}

Description: Thallus as solitary blades or multilayered turfs (Fig. 2A), delicate and fine. Blades oval, mesh-like membrane, one cell thick (Fig. 2 B,C). Branchlets with small, specialized, oval to spherical hapteroid cells, 40-80 $\mu \mathrm{m}$ diameter (Fig. 2D).

Voucher USJ: 73900, 73901.

Habitat: On dead coral, mixed with Dictyota sp.

Distribution recorded in Costa Rica: Playa Chiquita, Punta Cocles, Limón.

\section{Avrainvillea digitata}

D. S. Littler \& M. M. Littler, 1992

Description: Thallus gregarious and finger-like, dull dark brown-green (Fig. 3A). Interior siphons slightly moniliform (Fig. 3B), 40-60 $\mu \mathrm{m}$ diameter.

Voucher USJ: 73887.

Habitat: Growing as large mats on coral reefs. Found at less than $1 \mathrm{~m}$ to $5 \mathrm{~m}$ deep.

Distribution recorded in Costa Rica: Playa Chiquita, Punta Cocles, Limón. 
TABLE 1

Taxonomy of the new records found in the southern Caribbean of Costa Rica

\begin{tabular}{clll}
\multicolumn{1}{c}{ Phylum } & \multicolumn{1}{c}{ Orden } & \multicolumn{1}{c}{ Family } & \multicolumn{1}{c}{ Species } \\
Chlorophyta & Cladophorales & Anadyomenaceae & Microdictyon curtissiae W. R. Taylor \\
& Bryopsidales & Dichotomosiphonaceae & Avrainvillea digitata D. S. Littler \& Littler \\
& & Udoteaceae & Rhipidosiphon floridensis D. S. Littler \& Littler \\
Ochrophyta & Fucales & Sargassaceae & Turbinaria tricostata E. S. Barton \\
Rhodophyta & Ceramiales & Delesseriaceae & Augophyllum wysorii Showe M. Lin, Fredericq \& Hommersand \\
& Nemastomatales & Nemastomataceae & Predaea sp. \\
\hline
\end{tabular}
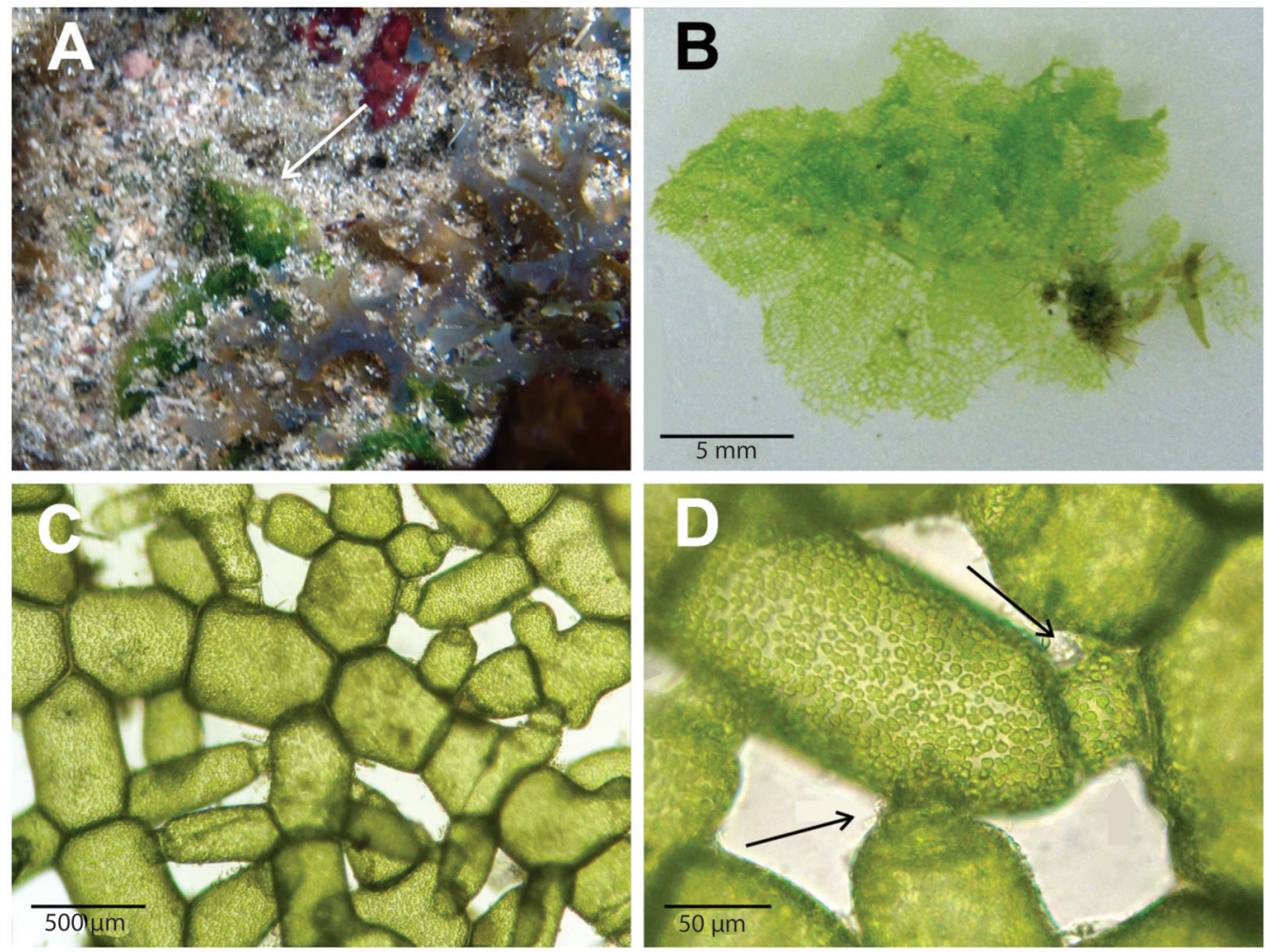

Fig. 2. Microdictyon curtissiae. A. Multilayered turfs in a coral reef. B. Thallus with various blades. C. Mesh-like network of blade. D. Hapteroid cells of branchlets.

Rhipidosiphon floridensis

D. S. Littler \& M. M. Littler, 1990

Description: Thallus diminutive and inconspicuous, erect, between $0.7 \mathrm{~cm}$ and 0.9 $\mathrm{cm}$, with one calcified monostromatic blade on a monosiphonous stipe, light green (Fig. 4A). Blades fan-shaped, between $0.5 \mathrm{~cm}$ and 0.7 $\mathrm{cm}$ wide, fragile, delicate; consists of parallel siphons that are dichotomously branched, constricted at their forks, and laterally fused by calcium carbonate deposits. Stipe inconspicuous, $130-220 \mu \mathrm{m}$ diameter, $1 \mathrm{~mm}$ to 3 $\mathrm{mm}$ long, unbranched, uncorticated, simple, erect, smooth, consisting of a solitary siphon (Fig. 4B). 

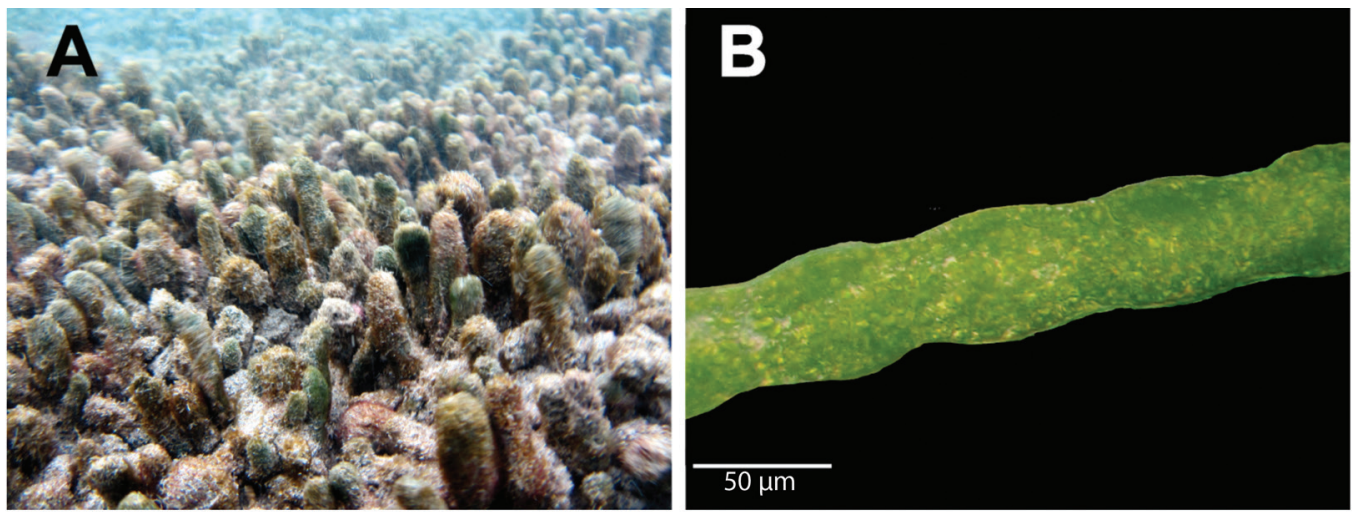

Fig. 3. Avrainvillea digitata. A. Finger-like thalli forming large mats on a coral reef. B. Moniliform interior siphon.
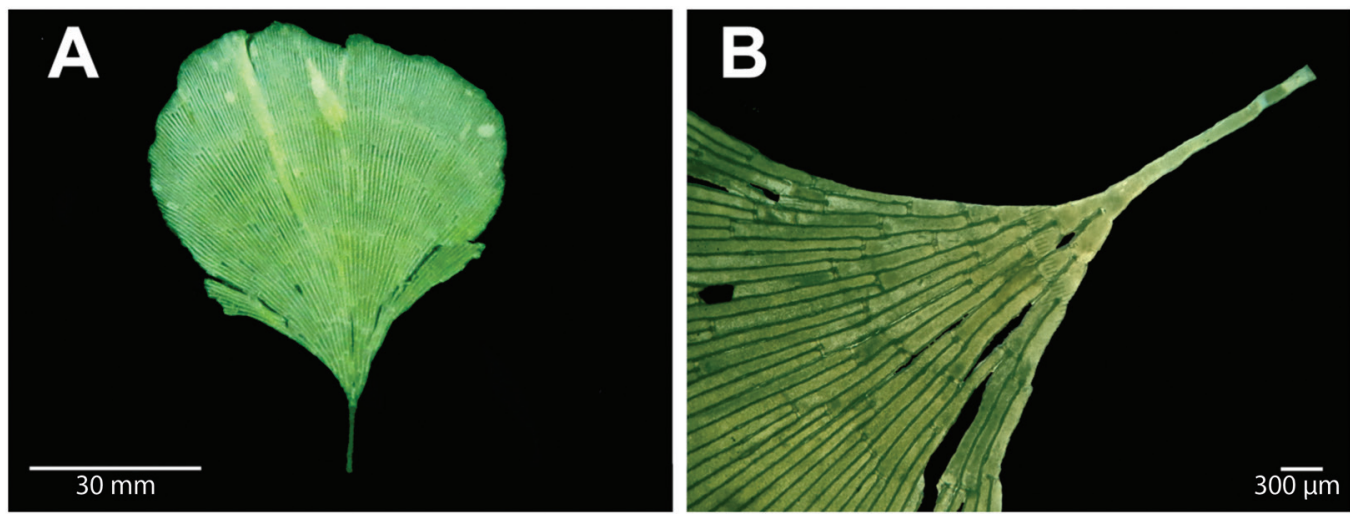

Fig. 4. Rhipidosiphon floridensis. A. Thallus, blade monostromatic. B. Stipe, monosiphonous.

Voucher USJ: 105808.

Habitat: Inconspicuous, attached to coral reef hard substrates between $2 \mathrm{~m}$ and $5 \mathrm{~m}$ deep.

Distribution recorded in Costa Rica: Playa Chiquita, Punta Cocles, Limón.

\section{Turbinaria tricostata}

E. S. Barton, 1981

Description: Thallus tough, $5.0-6.7 \mathrm{~cm}$ high, yellow-brown (before and after preserved), holdfast tough and branched (Fig. 5A). Branching alternate and sparse. Blades clustered distally, trialatus from above, transverse section narrowly triangular (Fig. 5B), 3-5 mm wide, $1-3 \mathrm{~cm}$ long, tapering towards stalk, apex concave, dentate ridges in apex and stalk (Fig. 5C). Air bladders deep in center of blade, not visible externally. Cryptostomata present, 150 $\mu \mathrm{m}$ to $200 \mu \mathrm{m}$ diameter (Fig. 5D).

\section{Voucher USJ: 73942.}

Notes: This species differs from Turbinaria. decurrens Bory de Saint-Vincent, 1828, Turbinaria murrayana E.S.Barton, 1891, and Turbinaria trialata (J. Agardh) Kützing, 1860 in the absence of vesicles. It also resembles $T$. turbinata, but differs from the former in the presence of toothed ridges on the stalk (Barton, 1891; Littler \& Littler, 2000).

Habitat: Growing on corallines rocks.

Distribution recorded in Costa Rica: Punta Uva, Puerto Viejo, Limón. 

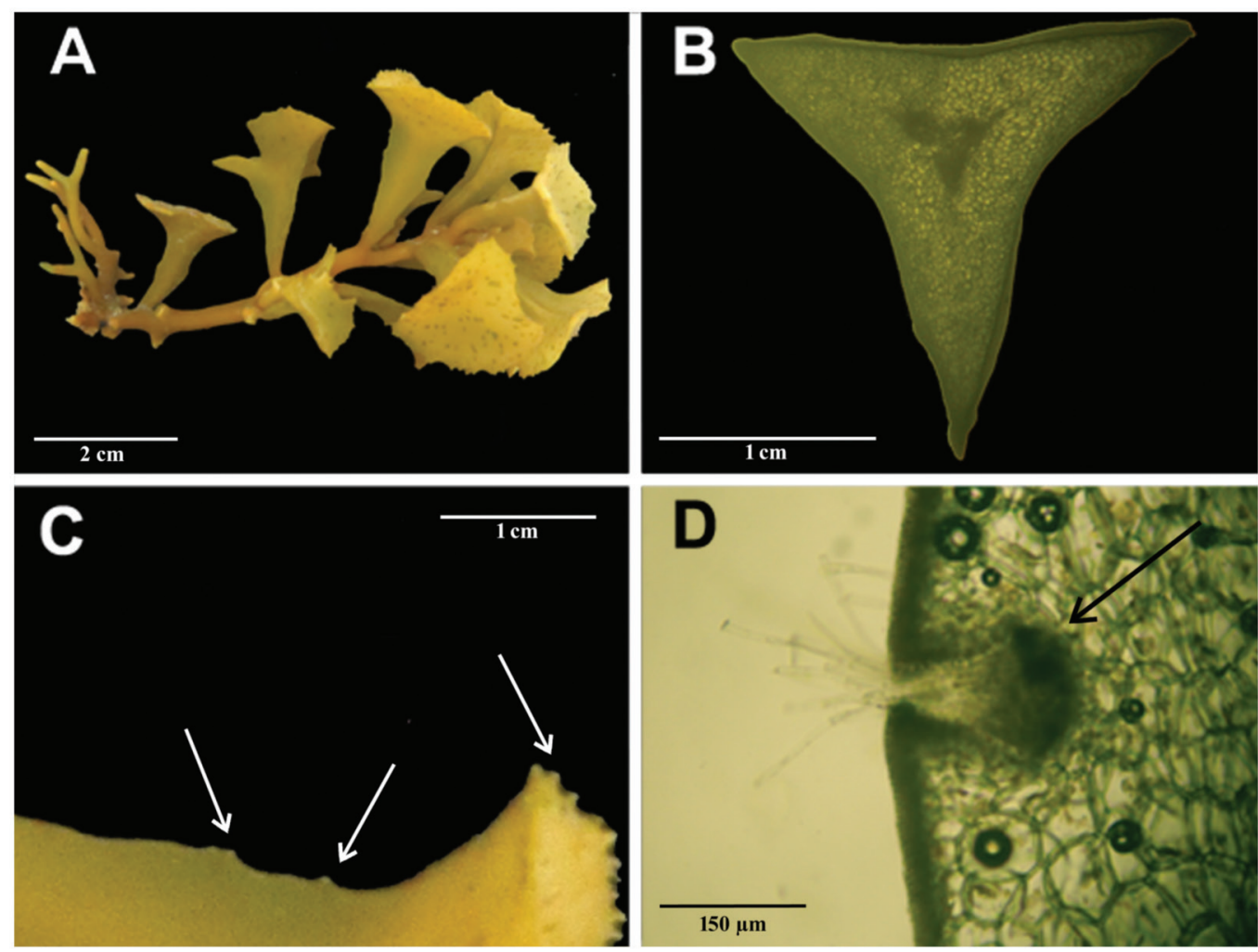

Fig. 5. Turbinaria tricostata. A. Thallus and holdfast. B. Blade, transversal view. C. Ridge of the stalk with small teeth. D. Cryptostomata, transverse section.

\section{Augophyllum wysorii}

Showe M. Lin, Fredericq \& Hommersand, 2004

Description: Thallus 2-3 cm tall with 1-3 ruffled, palmate blades arising from a single or branched stipe (Fig. 6A), blades pink (Fig. 6B), with bright golden iridescent spots (only in situ), polystromatic throughout interior of thallus (Fig. 6C), except at the margins that are monostromatic (Fig. 6D).

Voucher USJ: 73917.

Habitat: Found at $4 \mathrm{~m}$ depth.

Distribution recorded in Costa Rica: Playa Chiquita, Punta Cocles, Limón.

\section{Predaea sp.}

Description: Thallus gelatinous, turgid. 3-5 cm high, pink to red color (Fig. 7A), and branching irregular (Fig. 7B). Cortical filaments dichotomously branched and composed of small and linear-oblong cells deeply pigmented, 2.5-4 $\mu \mathrm{m}$ diameter (Fig. 7C). Medulla composed of longitudinal filaments loosely arranged, 5-7.5 $\mu \mathrm{m}$ diameter, within mucilaginous gel (Fig. 7D). Gland cells absent.

Voucher USJ: 73935.

Notes: There were no reproductive structures.

Habitat: On coral reef substrate and in sand plains. Found from $7 \mathrm{~m}$ to $10 \mathrm{~m}$ deep.

Distribution recorded in Costa Rica: Playa Chiquita, Punta Cocles, Limón. 

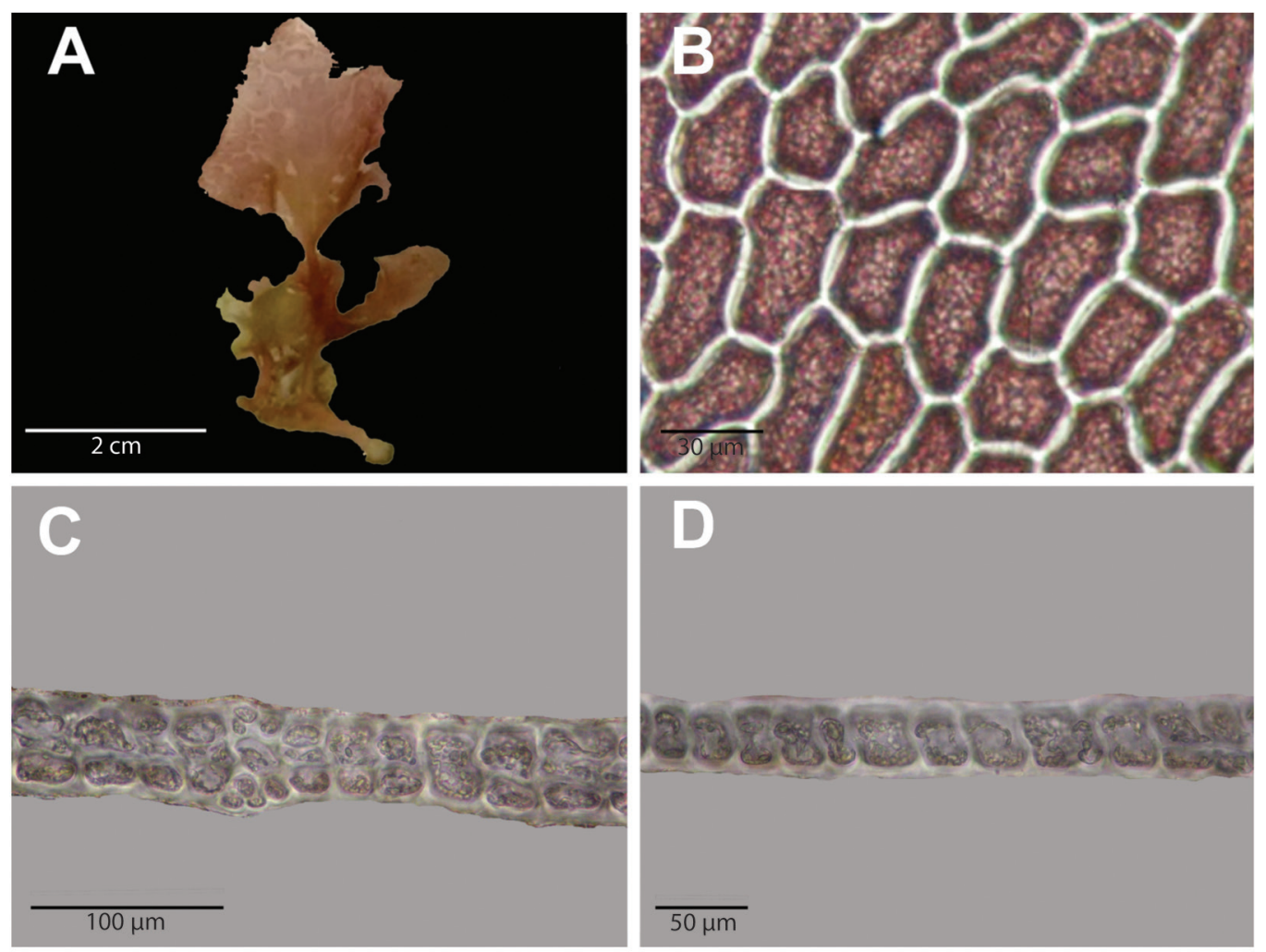

Fig. 6. Augophyllum wysorii. A. Palmate blades. B. Blade surface detail. C. Polystromatic arrangement through interior of thallus. D. Monostromatic arrangement at margin of the blades.

\section{DISCUSSION}

The six new records increased the diversity of Caribbean Costa Rican seaweeds by 1.9 $\%$ over that previously reported by Bernecker \& Wehrtmann (2009). Four new genera were recorded for Caribbean Costa Rica: Microdictyon, Rhipidosiphon, Predaea and Augophyllum. Although the majority of these new records were Chlorophyta, followed by Rhodophyta and Ochrophyta-Phaeophyceae they did not change the proportions of this groups within the total flora, where Rhodophyta is the most specious group. This overall pattern is found in all Central American countries (Bernecker \& Wehrtmann, 2009) and is typical for tropical regions (Strasburger, Noll, Schenck, \& Schimper, 1997).

In general, there is little information on the genus Microdictyon, however some species, such as Microdictyon boergesenii Setchell, 1925 have been referred as characteristic of “deep" waters (Hanisak \& Blair, 1988). Some species been also reported to be part of the diet of different animal groups. For example, the tube-dwelling polychaete Diopatra leuckarti Kinberg, 1865 ingests algae attached to the mounds where its tubes are built, including Microdictyon stechellianum M. A. Howe, 1934 (Bailey-Brock, 1984). A previous study on the diet of the fanbellied leatherjacket, Monacanthus chinensis (Osbeck, 1765) did report on the predation on Microdictyon umbilicatum (Velley) Zanardini, 1862 (Conacher, Lanzing, \& Larkum, 1979). Another example is Elysia cf. furvacauda Burn, 1958, which retains Microdyction-plastids in autumn and winter at Botany Bay, Australia (Brandley, 1984). Another study did also suggest that the green turtle, 

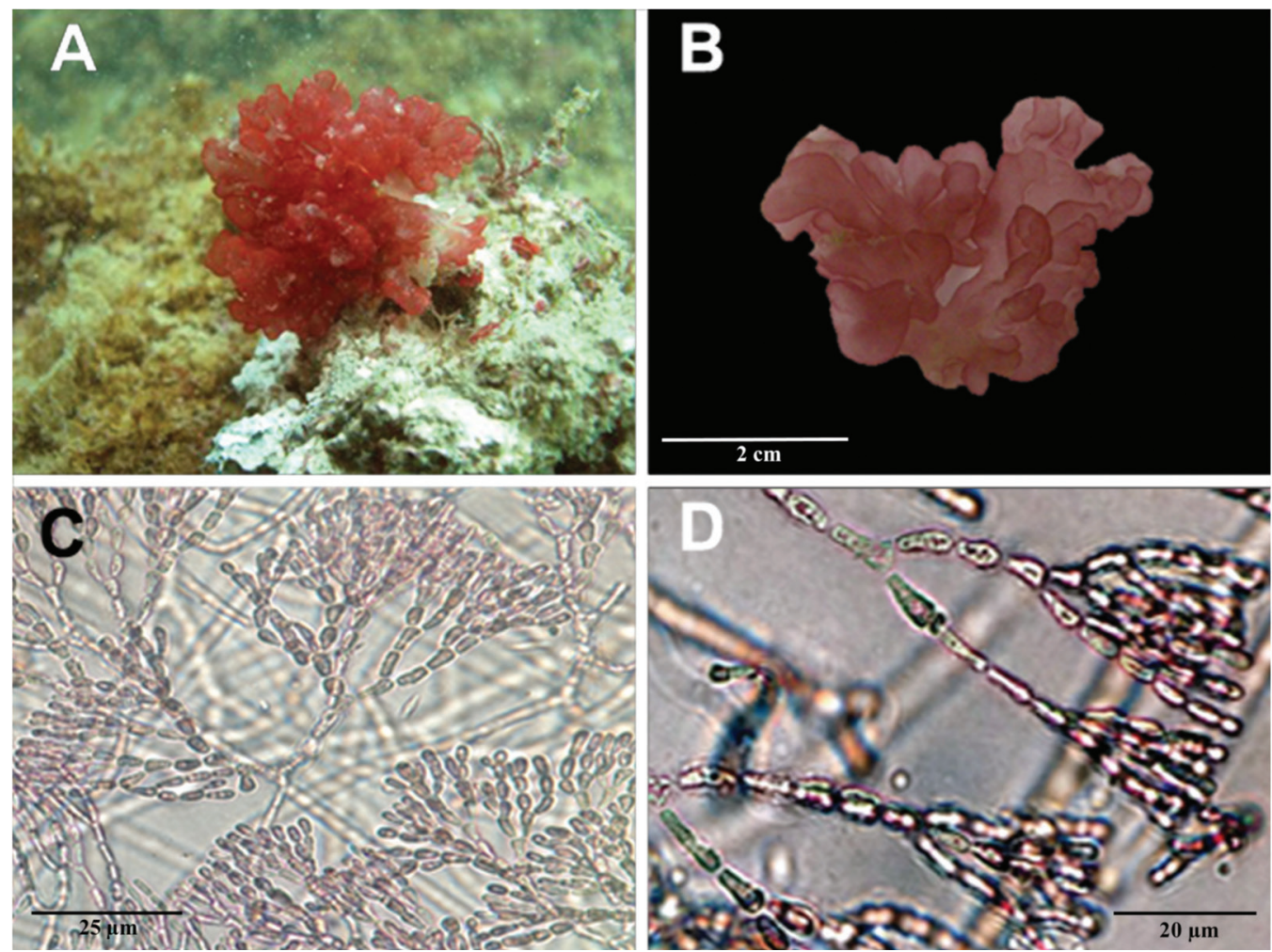

Fig. 7. Predaea sp. A. Thallus on a coral reef. B. Thallus with irregular branching. C. Cortical filaments dichotomously branching. D. Medulla and cortex cells.

Chelonia mydas (Linnaeus, 1758), may be ingesting Microdyction (Kolinski et al., 2006).

We found a large mat of $A$. digitata extending on the reef, although we did not measured its extension, although it spanned for more than $10 \mathrm{~m}^{2}$. In its original description, A. digitata was mentioned to present colonies up to 13 $\mathrm{cm}$ thick, and large mats of fronds were typically found at shallow waters, $<1 \mathrm{~m}$ (Littler \& Littler, 1992). Siphonal green algae possess a blade abandonment strategy linked to rapid proliferation processes, allowing these algae to dominate standing stocks in most calm-water reef habitats in the Caribbean (Littler \& Littler, 1999). However, some siphonal green algae have shown an invasive behavior. For example, Avrainvillea amadelpha (Montagne) A. Gepp \& E. S. Gepp, 1908 was first recorded in the Hawaiian archipelago in 1981, were Avrainvillea algae were recorded uncommon in the 50's and 70's, and appeared to spread from a small patch to several localities (Brostoff, 1989; Doty, Gilbert, \& Abbott, 1974). A. amadelpha is currently a highly successful invasive species in Hawaii, competing with native species such as Halophila hawaiiana Doty \& B. C. Stone, 1966 (Smith, Hunter, \& Smith, 2002). Recently, A. amadelpha was first recorded in the Mediterranean Sea (Verlaque, Langas, Hmida, Pergent, \& Pergent, 2017). The proliferation of this Avrainvillea mats have shown effects on the above-ground polychaete communities (Magalhães \& Bailey-Brock, 2014). Since this species have not been previously recorded nor its siphonal mats in these reefs (Fernández \& Alvarado, 2004), we suggest to keep a close monitoring on $A$. digitata coverage and its interactions with other benthic components.

Rhipidosiphon floridensis had been reported growing on rocky substrates with a fine 
sediment layer at $20 \mathrm{~m}$ in Bahía de Cochinos (Cuba), in coarse sand at $10 \mathrm{~m}$ in Galeta and at coral rubble at $22 \mathrm{~m}$ in Barren rock (both in Panama) (Sánchez, Martínez-Daranas, \& Suárez, 2017; Wysor \& Kooistra, 2003). These green algae had been also found as epiphytic, growing on Codium decorticatum (Woodward) M. A. Howe, 1911 in Isla Mujeres (Mexico) at $16.5 \mathrm{~m}$ (Mateo-Cid, Mendoza-González, \& Searles, 2002).

We found some patches of $T$. tricostata extending for several meters in the reefs of Playa Chiquita and Punta Uva. During previous visits at these reefs, we did not find this patches, therefore we suspect certain seasonality on the occurrence of $T$. tricostata that should be studied. In a nearby reef, other brown algae, Sargassum sp., do also occur in patches of several meters (Fernández \& Alvarado, 2004). Brown algae, such as Turbinaria, tend to dominate on rocky substrates at Cuban reefs (Zayas, Suárez, \& Ocaña, 2002). Turbinaria algae have shown seasonal variation in Sardinero, Justicí and Baconao reefs at Cuba, appearing only during the dry season (Jover, Reyes de Armas, Gómez, \& Suárez, 2012).

Augophyllum wysorii was found at shallower depths $(4 \mathrm{~m})$ than had been previously recorded, 12-15 m (Lin et al., 2004). This specie has a very restricted known distribution (Galeta STRI-Research Station, Colon, Panama) and therefore this Costa Rican record contributes to knowledge of the species range and habitat.

The Predaea sp. was found at a shallower depth than most of the Predaea species previously reported in the Caribbean (Ballantine \& Wynne, 1986; Delnatte \& Wynne, 2016; Gabriel, Schills, Neto, Paramio, \& Fredericq, 2009; Littler \& Littler, 2000; Rodríguez-Prieto, Michanek, \& Ivon, 1999). Although it is not possible to reach a species level with the observed morphological characteristics, it is probable that the species found corresponds to Predaea feldmannii Børgesen, 1950, a species recently described near to the Caribbean coast of Costa Rica (Gabriel et al., 2010).

This study found five new macroalgae species and one new genus during a short sampling period at two poorly studied localities. Further taxonomic studied including multiple localities and environments will likely reveal and even higher species richness along the Caribbean coast of Costa Rica. A detailed record of this biodiversity is necessary to improve future efforts in management and conservation. Biodiversity records also facilitate the quick detection of invasive species. Moreover, marine biodiversity is increasingly threatened by anthropogenic and natural impacts, and therefore we should improve our efforts to properly record it (Worm et al., 2006).

In addition, new herbarium records allow comparative studies, provide locality data for planning field trips, material for morphological observation, and serve as voucher specimens. Molecular analysis had been proven as an important tool for accurate identification of cryptic species of algae, e.g. Dictyota (Tronholm et al., 2013). Therefore, further studies using molecular analysis will be needed to improve our knowledge on the Costa Rican marine flora. Currently, we are trying to carry out molecular analysis in order to complement the results of the present study. In conclusion, this study provides six new records of marine macroalgae, increasing the known diversity of the Caribbean coast and provides important information for future ecological and taxonomy studies.

\section{ACKNOWLEDGMENTS}

We are grateful to family Alvarado-Barrientos for the permission to use their facilities and their support during the fieldwork. We are thankful to Andrés Beita for his comments on early stages of this manuscript. We thank Idea Wild for its contribution of photographic equipment. We are very grateful to Wilson Freshwater for his valuable comments on the manuscript and the revision of the English, which certainly helped to improve the quality of our contribution. We are also grateful with the anonymous reviewers who provided important inputs to improve this contribution. 


\section{RESUMEN}

Nuevos reportes de macroalgas marinas bénticas para la costa Caribe de Costa Rica. Las macroalgas marinas son un grupo muy diverso y juegan un rol importante en los ecosistemas marinos, influenciando procesos ecológicos. Registrar la diversidad de algas con una identificación taxonómica precisa es necesaria para entender los ecosistemas marinos. La biodiversidad de macroalgas en la costa del Caribe Sur de Costa Rica ha sido estudiada por varios autores, y un reciente listado incluye 396 especies de algas marinas bénticas, reportadas para las costas Pacífica y Caribe, de las cuales 287 están reportadas para el Caribe. El $80 \%$ del total de especímenes del Caribe depositados en colecciones botánicas en Costa Rica fueron colectados en el Parque Nacional Cahuita, sitio donde se han realizado la mayoría de estudios. Este estudio reporta la adición de cinco especies nuevas y un género nuevo de macroalgas marinas bénticas a la flora de la costa Caribe de Costa Rica encontradas en los arrecifes poco estudiado de Playa Chiquita y Punta Uva. El muestreo fue dirigido a buscar macroalgas bénticas utilizando equipo SCUBA y buceo a pulmón en Playa Chiquita y únicamente buceo a pulmón en Punta Uva, durante octubre del 2014. Los especímenes fueron depositados en el Herbario Dr. Luis A. Fournier Origgi (USJ) de la Universidad de Costa Rica. De los nuevos reportes, la mayoría fueron Chlorophyta, seguido por Rhodophyta y Ochrophyta-Phaeophyceae. Se documentaron cuatro nuevos géneros para todo el Caribe de Costa Rica: Microdictyon Decaisne, 1841, Rhipidosiphon Montagne, 1842, Predaea G. De Toni, 1936 and Augophyllum S.-M. Lin, S. Fredericq \& M. H. Hommersand, 2003. En conclusión, es necesario continuar los trabajos taxonómicos detallados, enfocándose en áreas pobremente estudiadas, para poder mejorar nuestro conocimiento sobre la flora marina de Costa Rica.

Palabras clave: Algas de arrecife, Biodiversidad marina, Chlorophyta, Colecciones, herbario Phaeophyceae, Rhodophyta.

\section{REFERENCES}

Bailey-Brock, J. H. (1984). Ecology of the tube-building polychaete Diopatra leuckarti Kinberg, 1865 (Onuphidae) in Hawaii: community structure, and sediment stabilizing properties. Zoological Journal of the Linnean Society, 80, 191-199. doi: 10.1111/j.10963642.1984.tb01972.x

Ballantine, D. L., \& Wynne, M. J. (1986). Notes on the marine algae of Puerto Rico. Botanica Marina, 39(2), 131-135. doi: 10.1515/botm.1997.40.1-6.39

Barton, E. S. (1891). A systematic and structural account of the genus Turbinaria, Lamx. Transaction of the Linnean Society of London, 3, 215-226.
Bernecker, A. (2009). Marine Benthic Algae. In I. S. Wehrtmann \& J. Cortés (Eds.). Marine Biodiversity of Costa Rica, Central America (pp. 109-117). Berlin, Germany: Springer Science + Business Media B.V.

Bernecker, A., \& Wehrtmann, I. S. (2009). New records of benthic marine algae and Cyanobacteria for Costa Rica, and a comparison with other Central American countries. Helgoland Marine Research, 63, 219-229. doi: 10.1007/s10152-009-0151-1

Brandley, B. K. (1984). Aspects of the ecology and physiology of Elysia cf. furvacauda (Mollusca: Sacoglossa). Bulletin of Marine Science, 34(2), 207-219.

Brostoff, W. N. (1989). Avrainvillea amadelpha (Codiales, Chlorophyta) from Oahu, Hawaii. Pacific Science, 43(2), 166-169.

Bruno, J. F., Boyer, K. E., Duffy, J. E., Lee, S. C., \& Kertesz, J. S. (2005). Effects of macroalgal species identity and richness on primary production in benthic marine communities. Ecology Letters, 8, 1165-1174. doi: 10.1111/j.1461-0248.2005.00823.x

Conacher, M. J., Lanzing, W. J. R., \& Larkum, A. W. D. (1979). Ecology of Botany Bay. II. Aspects of the feeding ecology of the fanbellied leatherjacket, Monacanthus chinensis (Pisces: Monacanthidae), in Posidonia australis seagrass beds in Quibray Bay, Botany Bay, New South Wales. Australian Journal of Marine and Freshwater Research, 30, 387-400. doi: 10.1071/MF9790387

Cortés, J. (1992). Los arrecifes coralinos del Refugio Nacional de Vida Silvestre Gandoca-Manzanillo, Limón, Costa Rica. Revista de Biología Tropical, 40(3), 325-333.

Cortés, J., \& Jiménez, C. E. (2003). Past, Present and Future of the Coral Reefs of the Caribbean Coast of Costa Rica. In J. Cortés (Ed.). Latin American Coral Reefs (pp. 223-239). Amsterdam, Netherlands: Elsevier Science B.V.

Cortés, J., Jiménez, C. E., Fonseca, A. C., \& Alvarado, J. J. (2010). Status and conservation of coral reefs in Costa Rica. Revista de Biología Tropical, 58(Suppl. 1), 33-50. doi: 10.15517/rbt.v58i1.20022

Costello, M. J., Michener, W. K., Gahegan, M., Zhang, Z. Q., \& Bourne, P. E. (2013). Biodiversity data should be published, cited, and peer reviewed. Trends in Ecology and Evolution, 28(8), 454-461. doi: 10.1016/j.tree.2013.05.002

Dawson, E. Y. (1962). Additions to the marine flora of Costa Rica and Nicaragua. Pacific Naturalist, 3(13), 375-395.

Delnatte, C., \& Wynne, M. J. (2016). A revised checklist of marine algae and seagrasses of Martinique, French West Indies. Nova Hedwigia, 103(3-4), 415-440. doi: $10.1127 /$ nova 
Doty, M. S., Gilbert, W. J., \& Abbott, I. A. (1974). Hawaiian marine algae from seaward of the algal ridge. Phycologia, 13(4), 345-357.

Fernández, C., \& Alvarado, J. J. (2004). El arrecife coralino de Punta Cocles, costa Caribe de Costa Rica. Revista de Biología Tropical, 52(Suppl. 2), 121-129.

Fletcher, W. J. (1987). Interactions among subtidal Australian sea urchins, gastropods, and algae: effects of experimental removals. Ecological Monographs, 57(1), 89-109. doi: 10.2307/1942640

Gabriel, D., Parente, M. I., Neto, A. I., Raposo, M., Schills, T., \& Fredericq, S. (2010). Phylogenetic appraisal of the genus Platoma (Nemastomatales, Rhodophyta), including life history and morphological observations on P. cyclocolpum from the Azores. Phycologia, 49(1), 2-21. doi: 10.2216/07-99.1

Gabriel, D., Schills, T., Neto, A. I., Paramio, L., \& Fredericq, S. (2009). Predaea feldmanni subsp. azorica (Nemastomataceae, Nemastomatales), a new subspecies of red algae (Rhodophyta) from the Azores. Cryptogamie, Algologie, 30(3), 251-270.

Guiry, M. D., \& Guiry, G. M. (2015). AlgaeBase. Worldwide electronic publication, National University of Ireland, Galway. Retrieved from http://www.algaebase.org

Hanisak, M. D., \& Blair, S. M. (1988). The deep-water macroalgal community of the East Florida continental shelf(USA). Helgoländer Meeresuntersuchungen, 42, 133-163. doi: 10.1007/BF02366040

Hay, M. E. (1981). Herbivory, algal distribution, and the maintenance of between-habitat diversity on a tropical fringing reef. The American Naturalist, 118(4), $520-540$.

Jover, A., Reyes de Armas, L. M., Gómez, L. M., \& Suárez, A. M. (2012). Variación espacial y temporal de las macroalgas del mesolitoral rocoso en AguadoresBaconao, Cuba I: composición. Revista de Investigaciones Marinas, 32(1), 38-49.

Kajimura, M. (1987). Two new species of Predaea (Nemastomataceae, Rhodophyta) from the Sea of Japan. Phycologia, 26(4), 419-428.

Kemperman, T. C. M., \& Stegenga, H. (1986). The marine benthic algae of the Atlantic side of Costa Rica. Brenesia, 25-26, 99-122.

Kolinski, S. P., Hoeke, R. K., Holzwarth, S. R., Ilo, L. I., Cox, E. F., O'Conner, R. C., \& Vroom, P. S. (2006). Nearshore distribution and an abundance estimate for green sea turtles, Chelonia mydas, at Rota Island, Commonwealth of the Northern Mariana Islands. Pacific Science, 60(4), 509-522. doi: $10.1353 /$ psc. 2006.0032
Lin, S. M., Fredericq, S., \& Hommersand, M. H. (2004). Augophyllum, a new genus of the Delesseriaceae (Rhodophyta) based on $r b c \mathrm{~L}$ sequence analysis and cystocarp development. Journal of Phycology, 40, 962-976. doi: 10.1111/j.1529-8817.2004.04055.x

Littler, D. S., \& Littler, M. M. (1992). Systematics of Avrainvillea (Bryopsidales, Chlorophyta) in the tropical western Atlantic. Phycologia, 31(5), 375-418.

Littler, D. S., \& Littler, M. M. (2000). Caribbean reef plants: An identification guide to the reef plants of the Caribbean, Bahamas, Florida and Gulf of Mexico. Washington, DC, USA: OffShore Graphics, Inc.

Littler, M. M., \& Littler, D. S. (1999). Blade abandonment/ proliferation: a novel mechanism for rapid epiphyte control in marine macrophytes. Ecology, 80(5), 1736-1746.

Magalhães, W. F., \& Bailey-Brock, J. H. (2014). Polychaete assemblages associated with the invasive green alga Avrainvillea amadelpha and surrounding bare sediment patches in Hawaii. Memoirs of the Museum Victoria, 71, 161-168.

Mateo-Cid, L. E., Mendoza-González, A. C., \& Searles, R. B. (2002). New Mexican records of marine algae including Crouania mayae sp. nov. (Ceramiaceae, Rhodophyta). Caribbean Journal of Science, 38(34), 205-221.

Rodríguez-Prieto, C., Michanek, G., \& Ivon, C. (1999). Benthic marine algae from Martinique (Lesser Antilles). Scientia Gerundensis, 24, 79-86.

Ruitton, S., Francour, P., \& Boudouresque, C. F. (2000). Relationships between algae, benthic herbivorous invertebrates and fishes in rocky sublittoral communities of a temperate sea (Mediterranean). Estuarine, Coastal and Shelf Science, 50, 217-230. doi: 10.1006/ ecss. 1999.0546

Sánchez, Y. A., Martínez-Daranas, B., \& Suárez, A. M. (2017). Adición a las clorofíceas cubanas: Rhipidosiphon floridensis D. Littler et M. Littler (Udoteaceae, Bryopsidales). Revista de Investigaciones Marinas, 37(1), 86-90.

Smith, J. E., Hunter, C. L., \& Smith, C. M. (2002). Distribution and reproductive characteristics of nonindigenous and invasive marine algae in the Hawaiian Islands. Pacific Science, 56(3), 299-315. doi: $10.1353 /$ psc. 2002.0030

Soto, R. (1983). Nuevos informes para la flora bentónica marina de Costa Rica. Brenesia, 21, 365-370.

Soto, R., \& Ballantine, D. L. (1986). La flora bentónica marina del Caribe de Costa Rica (notas preliminares). Brenesia, 25-26, 123-162. 
Strasburger, E., Noll, F., Schenck, H., \& Schimper, A. F. W. (1997). Tratado de Botánica. Barcelona, Spain: Ediciones Omega, S.A.

Taylor, W. R. (1933). Notes on algae from the tropical Atlantic Ocean II. Papers of the Michigan Academy of Science, Arts and Letters, 17, 395-407.

Taylor, W. R. (1942). Caribbean marine algae of the Allan Hancock Expedition, 1939. Reports of the Allan Hancock Atlantic Expedition, 2, 1-193.

Taylor, W. R. (1955). Notes on algae from the tropical Atlantic Ocean. IV. Papers of the Michigan Academy of Sciences, Arts and Letters, 40, 67-76.

Taylor, W. R. (1960). Marine algae of the eastern tropical and subtropical coasts of the Americas. Ann Arbor, USA: University of Michigan Press.

Thomas, D. T., \& Freshwater, D. W. (2001). Studies of Costa Rican Gelidiales (Rhodophyta): four Caribbean taxa including Pterocladiella beachii sp. nov. Phycologia, 40(4), 340-350.

Tronholm, A., Afonso-Carrillo, J., Sansón, M., Leliaert, F., Fernández-García, C., \& De Clerck, O. (2013). Taxonomy of the Dictyota ciliolata-crenulata complex (Dictyotales, Phaeophyceae). Phycologia, 52(2), 171-181. doi: 10.2216/12-005.1
Verlaque, M., Langas, H., Hmida, A. B., Pergent, C., \& Pergent, G. (2017). Introduction of a new potential invader into the Mediterranean Sea: the Indo-Pacific Avrainvillea amadelpha (Montagne) A. Gepp \& E.S. Gepp (Dichotomosiphonaceae, Ulvophyceae). Cryptogamie, Algologie, 38(3), 267-281.

Wellington, G. M. (1973). Additions to the Atlantic benthic flora of Costa Rica. Brenesia, 2, 17-20.

Wellington, G. M. (1974). The benthic flora of Punta Cahuita: an annotated list of species with new additions to the Costa Rican Atlantic flora. Brenesia, 3, 19-30.

Worm, B., Barbier, E. B., Beaumont, N., Duffy, J. E., Folke, C., Halpern, B. S., ... Watson, R. (2006). Impacts of biodiversity loss on ocean ecosystem services. Science, 314(5800), 787-790. doi: 10.1126/ science. 1132294

Wysor, B., \& Kooistra, W. H. C. F. (2003). An annotated list of marine Chlorophyta from the Caribbean coast of the Republic of Panama. Nova Hedwigia, 77(3-4), 487-523. doi: 10.1127/0029-5035/2003/0077-0487

Zayas, C. R., Suárez, A. M., \& Ocaña, F. A. (2002). Lista de especies y variación estacional del fitobentos marino de Playa Guardalavaca, Cuba. Revista de Investigaciones Marinas, 23(2), 81-84. 